\title{
Falta de saneamento básico e as águas subterrâneas em aquífero freático: região do Bairro Pedra Noventa, Cuiabá (MT)
}

\author{
Lack of sanitation and groundwater in shallow aquifer: region of the \\ neighborhood Pedra Noventa, Cuiaba (MT)
}
Débora Delatore da Silva1, Renato Blat Migliorini ${ }^{2}$, Edinaldo de Castro e Silva ${ }^{3}$, Zoraidy Marques de Lima ${ }^{4}$, Ivanete Barbosa de Moura ${ }^{5}$

\section{RESUMO}

A presente pesquisa teve por objetivo avaliar os impactos causados na qualidade química e bacteriológica das águas subterrâneas, do aquífero freático da região do bairro Pedra Noventa, em Cuiabá (MT). Para isso, foram selecionados 31 poços do tipo cacimba, distribuídos uniformemente ao longo desse bairro. Os resultados das análises permitiram as seguintes conclusões: 1 - Os parâmetros químicos estudados não apresentaram concentrações muito elevadas, embora o pH, a amônia, o nitrato e o fosfato tenham apresentado concentrações fora dos Valores Máximos Permissíveis para o consumo humano, exigidos pela Portaria 2.914/2011; provavelmente, originam-se das fossas sépticas, que estão disseminadas na região, e de matérias orgânicas em decomposição que caem nos poços abertos. 2 - A concentração dos elementos químicos entre os períodos de estiagem e chuva sofreu alterações em todos os parâmetros avaliados. Isto indica que ocorreram flutuações sazonais na sua qualidade, sendo as concentrações maiores na época da chuva e menores na época de estiagem, provavelmente pelo fato de os processos de lixiviação serem mais intensos que os processos de diluição. 3 - As análises bacteriológicas (coliformes totais e Escherichia coli) apresentaram concentrações acima dos Valores Máximos Permissíveis para o consumo humano, provavelmente graças às fossas sépticas intensamente distribuídas na região. 4 - As alterações provocadas nas águas subterrâneas do aquífero freático provavelmente se devem à falta de saneamento básico da região.

Palavras-chave: água subterrânea; qualidade química; qualidade bacteriológica; Pedra Noventa; Cuiabá (MT)

\begin{abstract}
This study aimed to assess the impacts on the bacteriological and chemical quality of groundwater, the water table aquifer in the area Neighborhood Ninety Stone in Cuiaba (MT). For this, we selected 31 wells venly distributed throughout this neighborhood. The analysis results led to the following conclusions: 1 - Chemical parameters studied did not show very high concentrations, although the $\mathrm{pH}$, ammonia, nitrate and phosphate have showed concentrations outside the Permissible Maximum Values for human consumption, required by Ordinance 2.914/2011; probably originate from septic tanks, which are widespread in the region and decomposing organic matter falling in open wells. 2 - Concentration of chemical elements between periods of drought and rain changed in all parameters evaluated. This indicates that there were seasonal fluctuations in quality, with the largest concentrations in the rainy season and lower in the dry season, probably due to leaching processes are more intense than the processes of dilution. 3 - The bacteriological analyzes (total coliforms and Escherichia coli) had concentrations above the Maximum Allowable Values for human consumption, probably due to septic tanks intensely distributed in the region. 4 - Changes in groundwater probably are due to lack of sanitation in the region.
\end{abstract}

Keywords: groundwater; chemical quality; bacteriological quality; Ninety Stone; Cuiaba (MT). \section{.}




\section{INTRODUÇÃO}

Embora a água seja necessária para praticamente todas as atividades humanas, atualmente encontramos problemas relacionados à quantidade e qualidade desse precioso recurso natural. Nesse contexto, o bairro Pedra Noventa, localizado na região sudeste de Cuiabá (MT), não foge à regra: enfrenta problemas de infraestrutura desde a sua implantação, e isso tem impulsionado a ocorrência de problemas relacionados à falta de recursos hídricos em condições adequadas. Uma das alternativas da população para usufruir de água foi à abertura de poços do tipo cacimbas.

Até alguns anos atrás, acreditava-se que as águas subterrâneas estavam naturalmente protegidas da contaminação pelas camadas dos solos e das rochas. Entretanto, a partir de então, passaram a serem detectados traços da presença de contaminantes em águas subterrâneas, e diversos estudos têm sido conduzidos no sentido de avaliar a sua qualidade (ALVES OLIVEIRA; SCHMIDT; FREITAS, 2004; FIORUCCI \& BENEDETTI FILHO, 2005; MARION; CAPOANE; SILVA, 2007; ATHAYDE et al., 2007; ZAVOUDAKIS, 2007; ROCHA, 2008; FREITAS, 2009; COLVARA; LIMA; SILVA, 2009; COSTA et al., 2010; BRASIL, 2010).

Diversos fatores podem comprometer a qualidade da água subterrânea. O destino final do esgoto doméstico e industrial em fossas e tanque sépticos, a disposição inadequada de resíduos sólidos urbanos e industriais, os postos de combustíveis e a modernização da agricultura representam fontes de contaminação das águas subterrâneas por bactérias e vírus patogênicos, parasitas, substâncias orgânicas e inorgânicas.

No bairro Pedra Noventa, na cidade de Cuiabá, é comum a prática da exploração das águas subterrâneas, pois os serviços de saneamento básico são insuficientes. Outro agravante é a falta de rede coletora de esgotos. A ineficiência desses serviços obriga a população local a construir fossas negras e sépticas dentro de seus terrenos para a deposição de efluentes, e frequentemente perfuram poços do tipo cacimba nas suas imediações. Essa pratica pode contaminar as águas subterrâneas, especialmente os aquíferos rasos (freáticos), possibilitando consequências drásticas na saúde coletiva.

Sendo assim, este estudo teve a finalidade de avaliar algumas características físicas, químicas e biológicas do aquífero freático do bairro Pedra Noventa, em Cuiabá (MT), no sentido de verificar possíveis focos de contaminação decorrentes da falta de saneamento básico, os quais comprometem a qualidade da água para o consumo humano.

\section{Caracterização geral da área objeto}

O clima da região é classificado como tropical semi-úmido da escala de KÖPPEN (GALVÃO, 1960), sua característica principal é a temperatura elevada $\left(18^{\circ}\right.$ a $\left.28^{\circ} \mathrm{C}\right)$, com amplitudes térmicas de $5^{\circ}$ a $7^{\circ} \mathrm{C}$, chegando a temperatura em torno de $45^{\circ} \mathrm{C} \mathrm{em}$ meses mais quentes. Outra característica marcante deste tipo de clima são as estações bem definidas de chuva e de seca. O índice pluviométrico é em torno de 1.500 mm/ano (APOITIA, 2003).
A área de estudo situa-se nos domínios geológicos do Grupo Cuiabá, pertencente à Faixa Interna de Dobramentos Paraguai, mais precisamente na Formação Rio Coxipó (MIGLIORINI, 1999). Essa Formação aflora principalmente na porção sul da cidade de Cuiabá, e no bairro Pedra Noventa encontramos Litofácies dos metadiamictitos com matriz argilosa, maciços de matriz arenosa e, mais raramente, silto-argilosa (MIGLIORINI, 1999).

O sistema aquífero na região é do tipo livre heterogêneo e anisotrópico, com intensa variação lateral e em profundidade. A matriz do corpo rochoso é caracterizada pela inexistência e/ou presença reduzida de espaços intergranulares. A água subterrânea encontra-se, preferencialmente, nas descontinuidades das rochas como fraturas, fissuras, diáclases e outras, isto é, nas porosidades secundárias. A trama e a intensidade dessas descontinuidades definem o potencial do aquífero. As rochas com esse tipo de armazenamento e circulação de águas subterrâneas, em hidrogeologia, são conhecidas como aquíferos fissurais (MIGLIORINI, 1999).

\section{Fontes potenciais de poluição das águas subterrâneas}

Segundo Freeze e Cherry (1979), uma das mais sérias consequências do lançamento de esgotos no solo, através de fossas sépticas, foi a contaminação da água subterrânea por alkyl benzeno sulfonatos (ABS). Vários casos de contaminação de aquíferos freáticos pouco profundos nos Estados Unidos foram descritos por Perimutter et al. (1964).

A partir de 1965, a indústria de detergentes substituiu o ABS pelo LAS (linear alkyl sulfonato), que é um composto biodegradável em ambiente aeróbio. Sendo assim, os casos de contaminação de poços por detergentes praticamente desapareceram, o que foi até certo ponto considerado surpreendente, porque muitos sistemas sépticos drenam para ambientes anaeróbios de água subterrânea, nos quais os efeitos da biodegradação provavelmente são mínimos. O LAS pode sofrer retardamento por adsorção (FEITOSA et al., 2008).

Os esgotos domésticos são uma das principais fontes de poluição química antrópica dos recursos hídricos nas áreas urbanas. No Brasil, o índice de coleta de esgotos domésticos é de 33,5\% e o tratamento chega a $35 \%$ do total coletado, o que perfaz um índice de tratamento de $11,7 \%$ do volume total de esgoto doméstico gerado. É esperado um aumento significativo no volume de tratamento de esgotos, mas, mesmo que o volume seja dobrado, o Brasil ainda vai ficar com um índice de tratamento de esgotos domésticos abaixo de 25\% (FINOTI et al., 2009).

A utilização das águas subterrâneas no Brasil é geralmente feita de forma empírica, improvisada e não controlada, resultando em frequentes problemas de interferências entre poços, redução dos fluxos de base dos rios, impactos em áreas encharcadas e redução das descargas de fontes e nascentes. No bairro Perda Noventa, a situação não 
é diferente; além disso, os poços inadequadamente construídos, operados e abandonados sem controle, transformam-se em verdadeiros focos de poluição das águas subterrâneas, sobretudo aqueles localizados no meio urbano (APOITIA, 2003).

Um aquífero freático, superficial, captado majoritariamente por poços de pequena profundidade, limitado na base por camadas impermeáveis, tem apenas interesse local, para uso doméstico e agrícola, sendo extremamente vulnerável à contaminação química, pela reduzida profundidade do nível freático (1 a 5 metros). Segundo Migliorini (1999), os aquíferos do Grupo Cuiabá apresentam grau de vulnerabilidade à poluição das águas subterrâneas relativamente alto. $\mathrm{O}$ manto de alteração, aliado às fraturas das rochas, apresenta-se normalmente vulnerável à infiltração de poluentes. Nas áreas onde a espessura da zona não saturada é maior, o aquífero tem maior poder de autodepuração, e nas áreas onde o nível d'água é raso, a vulnerabilidade à contaminação aumenta, facilitando a exposição à poluição, por infiltração de substâncias perigosas ou por micro-organismos.

Segundo Pereira (2004) a água pode ser infectada por organismos patogênicos, existentes nos esgotos. Assim ela pode conter: bactérias, as quais provocam infecções intestinais epidérmicas e endêmicas; vírus: provocam hepatites e infecções nos olhos; protozoários: responsáveis pelas amebíases e giardíases; vermes: esquistossomose e outras infestações.

Um dos mais importantes aspectos de poluição das águas está relacionado com a contaminação por coliformes totais e fecais, que está diretamente associada a doenças que têm como veículo a água (APOITIA, 2003). Esse parâmetro permite avaliar de forma indireta o potencial de contaminação da água por patogênicos de origem fecal (REETZ, 2002). Pinfold (1990), em trabalho realizado nas Filipinas, verificou que crianças que consumiram água altamente poluída com matéria fecal tiveram uma ocorrência de diarreia significativamente maior que aquelas que consumiram águas com menor nível de poluição.

A maioria das doenças de veiculação hídrica pode ser consideravelmente reduzida, desde que a população tenha acesso à água potável. Entretanto, um dos maiores problemas das fontes particulares é a ausência de monitoramento da qualidade da água consumida (MISRA, 1975). A Portaria 2.914 do Ministério da Saúde estabelece que, para populações residentes em áreas indígenas, populações tradicionais, entre outras, $\mathrm{o}$ plano de amostragem para o controle de qualidade da água deverá ser elaborado de acordo com as diretrizes específicas aplicáveis a cada situação (BRASIL, 2011). Encarregar o próprio consumidor de controlar a qualidade da água é uma postura incorreta, uma vez que o seu conhecimento quanto aos riscos que a água pode oferecer à saúde é praticamente inexistente (AMARAL et al., 2003). O uso de água subterrânea contaminada, não tratada ou inadequadamente desinfetada foi responsável por $44 \%$ dos surtos de doenças de veiculação hídrica nos Estados Unidos entre 1981 e 1988 (CRAUN, 1991).
Quando as bactérias são transportadas com a água subterrânea no meio poroso, elas são removidas por filtração e adsorção, de maneira que seu avanço é muito retardado em relação à velocidade do fluxo advectivo. Em áreas médias ou em materiais mais finos, organismos patogênicos e coliformes somente conseguem penetrar alguns metros (KRONE; McGAUHEY; GOTAAS, 1957). Estudos de campo, todavia, mostraram que, em aquíferos heterogêneos de areia ou cascalho, bactérias oriundas de esgotos podem ser transportadas por dezenas ou centenas de metros na água subterrânea (KRONE et al., 1957; WESNER \& BAIER, 1970).

\section{METODOLOGIA}

\section{Localização e delimitação cartográfica dos pontos de amostragem}

Para identificação dos pontos de amostragem foram realizadas expedições no mês de março de 2010, nas quais foram selecionados 31 poços em toda a área do bairro Pedra Noventa. Os critérios utilizados para a localização das estações de amostragem foram: a necessidade de que esses locais fossem distribuídos de forma homogênea na área e a proximidade de fossas negras. Em julho de 2010, iniciou-se o cadastramento dos poços de monitoramento, os quais foram georreferenciados.

\section{Coleta das amostras de água}

Em julho de 2011, período considerado seco, iniciaram-se as coletas de amostras de água para a realização das análises químicas, sendo concomitantemente determinado no campo o $\mathrm{pH}$. Para os parâmetros microbiológicos, as coletas foram realizadas apenas no período chuvoso (novembro de 2011 e fevereiro de 2012). Nos pontos C15 e C17 não foi possível realizar a coleta de água em novembro de 2012, pois a lâmina d'água estava muito fina e no ponto C26 por ausência do proprietário; sendo assim, nesse mês foram coletados apenas 27 pontos.

As amostras de água foram coletadas na boca do poço, em triplicata, utilizando amostrador manual bailer, acondicionadas em recipientes apropriados, preservadas e refrigeradas durante o transporte, de acordo com padrões da CETESB (1998). As coletas para as análises bacteriológicas foram as primeiras a serem realizadas e, posteriormente, o material coletado foi transferido para bolsas plásticas estéreis de 300 mL (NASC-B01254WA da NASCO ${ }^{\circledR}$ ) contendo tiossulfato de sódio.

As amostras de água foram analisadas segundo Standard Methods of Examination of Water and Wasterwater (APHA, 1998).

\section{Determinação dos parâmetros químicos}

As medidas de $\mathrm{pH}$ foram realizadas utilizando-se um peagâmetro portátil da marca WTW modelo pH340, sendo utilizado o método eletrométrico e ajustado com soluções tampão pH 4,00 e 7,00. 
Para a determinação do teor de cátions e ânions nas amostras coletadas, foram utilizados os métodos modificados Dionex Aplication Note 141 e o Method U.S.EPA-300.1 Determination of Inorganic Anions in Drinking Water by Ion Chromatography, respectivamente, no qual as amostras não preservadas foram filtradas em filtros de membrana de celulose de $0,22 \mu \mathrm{m}$ de diâmetro do poro e, quando necessário, em membrana de acetato de celulose $0,45 \mu \mathrm{m}$ (Millipore ${ }^{\circledR}$ ). Transferiu-se o filtrado para um frasco antecipadamente identificado e lavado com solução de Extran, solução básica e água morna deionizada; em seguida, foi armazenado sob refrigeração até a execução do ensaio.

Os cátions e ânions presentes nas amostras foram determinados por cromatografia de íons, num equipamento Dionex com detector de condutividade elétrica, modelo ICS 90 e ICS 1000. As condições de trabalho para cada um dos módulos cromatográficos são apresentadas a seguir. Módulo ICS 90: coluna cromatográfica AS9 9-HC, com supressora AMMS 300, fluxo de 1,0 mL. $\mathrm{min}^{-1}$, detector DS5, solução eluente de carbonato de sódio $\left(\mathrm{Na}_{2} \mathrm{CO}_{3}\right)-9,0 \mathrm{mM}$ e solução regenerante de ácido sulfúrico $\left(\mathrm{H}_{2} \mathrm{SO}_{4}\right)-25 \mathrm{mM}$. Módulo ICS 1000: coluna cromatográfica IONPAC CS16, com supressora CSRS 300, fluxo de 0,36 mL.min ${ }^{-1}$, detector DS3 e solução eluente de ácido sulfúrico $\left(\mathrm{H}_{2} \mathrm{SO}_{4}\right)-20 \mathrm{mM}$.

A quantificação das espécies iônicas foi realizada com base na curva de calibração, pelo método de padronização externa; foram construídas curvas analíticas contendo 5 pontos, ou seja, foram preparados cinco padrões mistos de concentrações variadas por diluição da solução padrão estoque Dionex, que apresenta um mix de 6 componentes, tanto o padrão de componentes catiônicos quanto os aniônicos. Esse procedimento foi executado para a quantificação dos cátions e ânions presentes nas amostras.

Os limites de quantificação para cada uma das espécies iônicas analisadas foram: nitrito $\left(\mathrm{NO}_{2}^{-}\right)$e nitrato $\left(\mathrm{NO}_{3}^{-}\right) 0,4 \mathrm{mg} \cdot \mathrm{L}^{-1}$, fosfato $\left(\mathrm{PO}_{4}^{-3}\right)$ 0,6 mg. $\mathrm{L}^{-1}$ e amônia $\left(\mathrm{NH}_{3}\right)$ 0,25 mg. $\mathrm{L}^{-1}$.

\section{Determinação dos parâmetros bacteriológicos (Coliforme total, Escherichia coli e bactérias heterotróficas)}

As análises bacteriológicas para a determinação de coliformes totais e Escherichia coli foram realizadas pelo método de substrato cromogênico definido ONPG-MUG (Collilert $\left.{ }^{\circledR}\right)$; e, para realizar a contagem de bactérias heterotróficas mesófilas cultiváveis, foi utilizado o método de Contagem Padrão em Placas (CPP), fazendo uso da técnica de Pour Plate (APHA, 1998). Ambos os ensaios foram executados no Laboratório de Microbiologia Sanitária do Departamento de Engenharia Sanitária e Ambiental, da Universidade Federal de Mato Grosso.

\section{RESULTADOS E DISCUSSÃO}

Apreensivos com a falta de saneamento básico, como ausência de rede coletora de esgoto e uso indiscriminado de poços do tipo cacimba, verificou-se a necessidade do estudo da qualidade das águas subterrâneas do aquífero freático.

\section{Potencial hidrogeniônico $(\mathrm{pH})$}

O parâmetro $\mathrm{pH}$ (potencial hidrogeniônico) é a medida da concentração hidrogeniônica, ou seja, íons $\mathrm{H}^{+}$presentes na água. Calculado como o logaritmo negativo da concentração de $\mathrm{H}^{+}$, é resultante inicialmente da dissociação das próprias moléculas da água e posteriormente acrescida pelos íons hidrogênio provenientes de outras fontes. $\mathrm{O} \mathrm{pH}$ é essencialmente função do gás carbônico dissolvido e da alcalinidade da água; assim, pode indicar condição de acidez, alcalinidade ou neutralidade da água e pode ser resultante de fatores naturais e antrópicos (ROCHA, 2008).

Nos poços estudados, os resultados de $\mathrm{pH}$ encontrados indicaram águas levemente ácidas, cuja média dos valores permaneceram em torno de 5,0 (Figura 1), variando entre aproximadamente 4,2 a cerca de 7,0; o desvio dos valores em relação à média foi muito baixo, cerca de 0,7 - ou seja, durante o monitoramento, os valores de $\mathrm{pH}$ mantiveram-se quase que constantes. Apenas o ponto C25 se diferenciou dos demais poços, apresentando um valor um pouco mais baixo.

A Portaria 2.914/2011 do Ministério da Saúde (BRASIL, 2011) recomenda que no sistema de distribuição o $\mathrm{pH}$ da água seja mantido na faixa de 6,0 a 9,5. Assim, grande parte das amostras encontra-se fora do Valor Máximo Permitido (VMP) para consumo. Em julho de 2011 (período de estiagem), cerca de $80 \%$ dos valores de $\mathrm{pH}$ encontram-se abaixo do VMP para consumo; para os meses de novembro de 2011 (início do período chuvoso) e fevereiro (final do período chuvoso), cerca de $70 \%$ dos valores encontram-se abaixo do valor mínimo permitido.

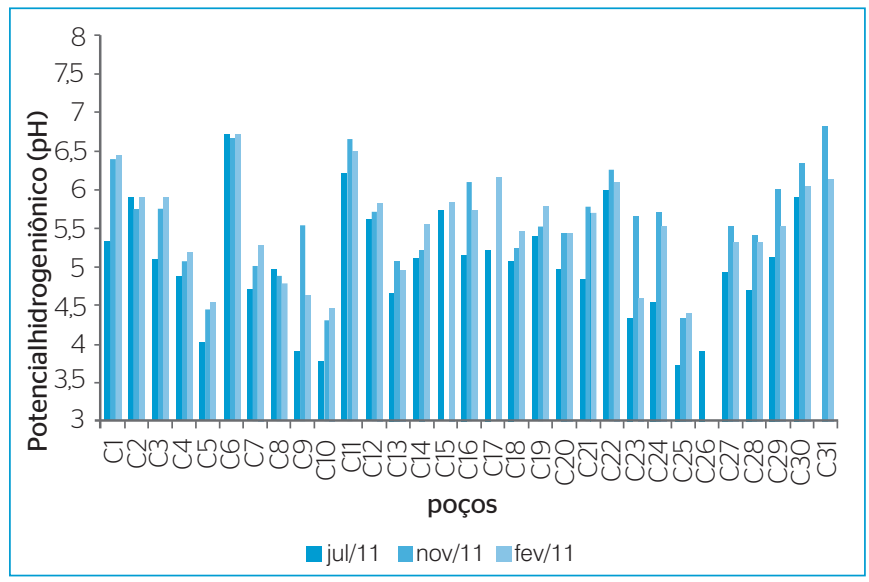

Figura 1 - Potencial hidrogeniônico (pH). 
Foi observado que os valores de $\mathrm{pH}$ foram menores para o período de estiagem, se comparado aos valores apresentados para os períodos chuvosos. $\mathrm{O}$ pH é um parâmetro sazonal em relação à precipitação, ou seja, no período seco os valores apresentam-se menores. Possivelmente, esse fato seja o reflexo da contribuição de íons hidrogênio provenientes da lixiviação de matéria orgânica em decomposição e das rochas carbonáticas, que, segundo Migliorini (2004), é muito comum nas rochas do Grupo Cuiabá. A região centro-sul da área se destaca pelos baixos valores de $\mathrm{pH}$, principalmente no período de estiagem.

\section{Cátion $\left(\mathrm{NH}_{4}^{+}\right)$e ânions $\left(\mathrm{NO}_{3} ; \mathrm{NO}_{2} ; \mathrm{PO}_{4}^{-2}\right)$}

Antes do desenvolvimento das análises bacteriológicas, as evidências da contaminação das águas eram determinadas pelas concentrações de nitrogênio nas suas diferentes formas: nitrato, nitrito e nitrogênio amoniacal.

A decomposição da matéria orgânica em sistema aquático origina a formação de compostos nitrogenados reduzidos - por exemplo, a amônia e o íon amônio. A oxidação biológica desses compostos leva à formação de íons nitrato $\left(\mathrm{NO}_{3}^{-}\right)$, e esse processo é conhecido como nitrificação (ANA, 2002).

Concentrações elevadas de nitrogênio orgânico ou nitrogênio amoniacal indicam poluição recente, tendo em vista que as formas bioquimicamente interconversíveis e componentes do ciclo do nitrogênio são: $\mathrm{N}_{\text {org }}-\mathrm{NH}_{3}-\mathrm{NO}_{2}^{-}-\mathrm{NO}_{3}^{-}$(CELLIGOI, 1999).

O nitrogênio amoniacal (amônia + íon amônio) se apresenta em duas formas dissolvidas: o amoníaco ou amônia não ionizada $\left(\mathrm{NH}_{3}\right)$ e o íon amônio $\left(\mathrm{NH}_{4}^{+}\right)$, cujas proporções dependem do $\mathrm{pH}$, da temperatura e da salinidade presentes no ambiente. Como o nitrogênio na forma de amônia não ionizada é mais tóxico, as concentrações de $\left(\mathrm{NH}_{4}^{+}\right)$podem se elevar sem que sua toxidade seja crítica, se o $\mathrm{pH}$ e a temperatura se mantiveram dentro de certos limites. Altos valores do íon amônio são encontrados em ambientes anóxicos, onde ocorre uma intensa mineralização anaeróbica da matéria orgânica, e em locais próximos a efluentes urbanos (REIS \& MENDONÇA, 1995).

Em condições normais, a amônia encontra-se em concentrações muito baixas em águas subterrâneas, menor que $10 \mu \mathrm{g} . \mathrm{L}^{-1}$ de nitrogênio, em virtude de ser adsorvida pelas partículas do solo, principalmente pelas argilas, e também por não ser facilmente lixiviada (STANDARD, 1985).

Na Figura 2 observam-se os valores da concentração de amônia $\left(\mathrm{NH}_{3}\right)$, obtidos para os pontos monitorados na área de estudo.

A maior concentração de amônia encontrada foi observada na cacimba C2 tanto no período de estiagem como no início do período chuvoso. No entanto, comparando os dois períodos monitorados, no início do período chuvoso os valores obtidos destacaram-se, apenas nas cacimbas C2, C8 e C10, apresentando os maiores valores de concentração de amônia no período de estiagem.

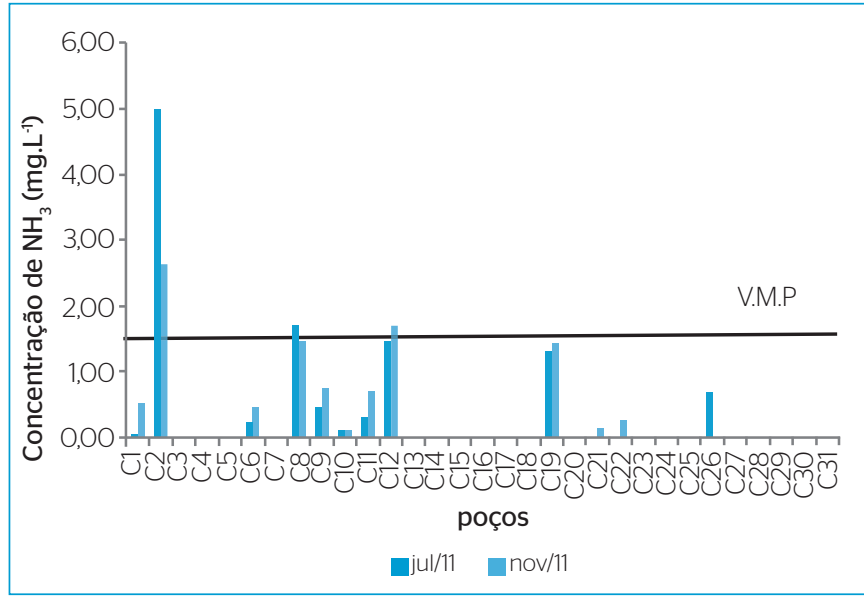

Figura 2 - Teor de amônia $\left(\mathrm{NH}_{3}\right)$ no período de estiagem e início do período chuvoso.

De acordo com observações realizadas em campo durante a coleta, verificou-se, na cacimba C2, que o aspecto da água era amarelada, com odor e algumas partículas em suspensão, apresentando uma turbidez considerável. Esse ponto distancia-se da fossa em aproximadamente $15 \mathrm{~m}$ e, segundo informação do proprietário, sempre no período chuvoso se faz necessário o esgotamento da fossa em razão da elevação do nível d'água.

Segundo a Portaria 2.914/2011 (BRASIL, 2011), o Valor Máximo Permissível (VMP) para o consumo humano é de 1,5 mg.L-1'; os valores de concentração de amônia acima do VMP certamente estão ligados à contaminação recente por esgotos domésticos, fossas sépticas, excrementos e fezes de animais, ou mesmo aos fertilizantes nitrogenados.

A decomposição da matéria orgânica em sistemas aquáticos possui ampla relação com o ciclo do nitrogênio, que conta com a intensa participação de bactérias, tanto no processo de nitrificação (oxidação bacteriana da amônia, normalmente oriunda da matéria orgânica, a nitrito e deste a nitrato) quanto na desnitrificação (redução bacteriana do nitrato ao gás nitrogênio) (FIORUCCI \& BENEDETTI FILHO, 2005).

Fortemente encontrado na natureza, na forma de proteínas e outros compostos orgânicos, o nitrogênio tem uma significativa origem antropogênica, principalmente em decorrência do lançamento em corpos d'água de despejos domésticos e industriais, assim como de fertilizantes (COSTA et al., 2010), quando seu teor for maior que 5 mg.L - $^{-1}$ (FEITOSA et al., 2008). O nitrato em concentrações elevadas está associado à meta-hemoglobinemia, doença que dificulta o transporte de oxigênio na corrente sanguínea de bebês. Em adultos, a atividade metabólica interna impede a conversão do nitrato em nitrito, que é o agente responsável por essa enfermidade (FERNÍCOLA \& AZEVEDO, 1981).

O nitrato é muito móvel e pode ser removido das camadas superiores do solo para a água; representa o estágio final da oxidação de matéria orgânica e ocorre em geral em pequenos teores 
(FEITOSA et al., 2008). Segundo o padrão de potabilidade do Ministério da Saúde, por meio da Portaria 2.914/2011 (BRASIL, 2011), uma água não deve ter mais que $10 \mathrm{mg} \cdot \mathrm{L}^{-1}$ de $\mathrm{N}^{-\mathrm{NO}_{3}}{ }_{3}^{-}$se destinada ao consumo humano.

Os resultados obtidos para o teor de nitrato no presente estudo podem ser observados na Figura 3, e as concentrações estão expressas em nitrato na forma de nitrogênio.

Os valores obtidos para o teor de nitrato na forma de nitrogênio indicaram uma alta variabilidade espacial. As concentrações variaram abaixo do limite de detecção, a 10,83 mg..-1 , apresentando média de 4,6 mg.L $\mathrm{L}^{-1}$ para ambos os períodos monitorados. No entanto, foi observado que o valor máximo obtido da concentração de nitrato ocorreu no período de estiagem na cacimba C25, apresentando o valor de 10,83 mg. $\mathrm{L}^{-1}$ de $\mathrm{N}-\mathrm{NO}_{3}$. Apenas esse ponto se apresentou acima do Valor Máximo Permissível pela Portaria 2,914/2011 do Ministério da Saúde (BRASIL, 2011). Porém, os maiores valores encontrados da concentração de nitrato foram obtidos no início do período chuvoso.

É interessante observar que, embora as concentrações de nitrato estejam na sua grande maioria abaixo dos valores permitidos pelas legislações citadas, esses valores estão relativamente altos. Apesar de apenas um ponto ter apresentado resultado acima do limite especificado pela legislação para consumo humano, é importante mencionar que há pontos monitorados que, no período de estiagem, não apresentaram resultado significativo e que, no início do período chuvoso, obtiveram resultado consideravelmente maior. Isso chama a atenção para a facilidade de contaminação do aquífero freático por fossas negras (em grande número na região em estudo), possivelmente em razão da proximidade do nível da água à superfície do terreno, sendo mais intensa no período chuvoso.

$\mathrm{Na}$ região centro-sul, há pontos que apresentam as maiores concentrações de nitrato para ambos os períodos monitorados, bem como

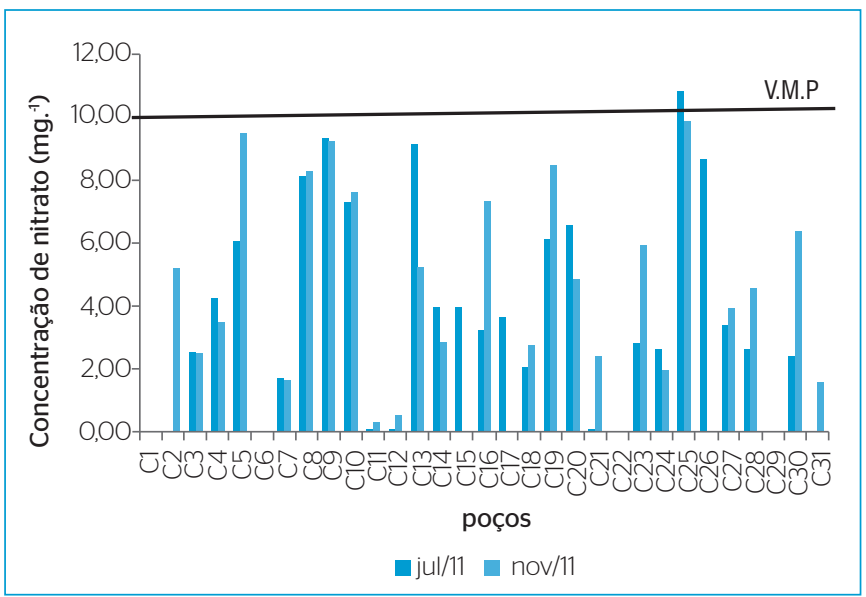

Figura 3 - Teor de nitrato na forma de nitrogênio para o período de estiagem e início do período chuvoso. na região oeste da área, a cacimba C13 apresenta concentração elevada de nitrato $\left(\mathrm{N}-\mathrm{NO}_{3}{ }^{-}\right)$no período de estiagem, mas, no início do período chuvoso, ocorre a sua diluição. Esperava-se que no início do período chuvoso as concentrações de $\mathrm{N}^{-\mathrm{NO}_{3}}$ - fossem apresentar maiores valores, por causa da proximidade do nível da água em relação à superfície do terreno; no entanto, observa-se que em 13 pontos monitorados os teores de nitrato realmente são maiores no início do período chuvoso.

A presença de nitritos em água indica processos biológicos ativos influenciados por poluição orgânica. Normalmente, é encontrado em quantidades diminutas nas águas superficiais, pois é instável na presença de oxigênio, ocorrendo como uma forma intermediária.

Os processos bioquímicos de oxidação do amônio ao nitrito e deste para nitrato implicam o consumo de oxigênio dissolvido, ou seja, altas concentrações de nitrito podem significar uma grande atividade bacteriana e carência de oxigênio no corpo hídrico, seja ele superficial ou subterrâneo (PEREIRA, 2004).

Os resultados obtidos para concentração de nitrito expresso em nitrogênio no presente estudo mostraram que nenhum dos pontos amostrados apresentou resultado para o teor de nitrito, o que pode indicar que todas as formas de nitrogênio nas amostras analisadas estão na forma de amônia não ionizada, ou seja, adquiridas recentemente ou na forma mais oxidada, após a nitrificação para nitrato. Na segunda campanha de coleta (início do período chuvoso) não foi possível realizar os ensaios para a determinação da concentração de nitrito.

No ambiente aquático, o fósforo pode ser encontrado sob várias formas: orgânica (matéria orgânica dissolvida e particulada na biomassa) e inorgânica (fração solúvel, representada pelos sais de fósforo dissolvidos, e insolúvel, representada pela presença de minerais de difícil solubilização). A fração mais significativa no estudo do fósforo é a inorgânica solúvel $\left(\mathrm{PO}_{4}^{-2}\right)$, que pode ser diretamente assimilada para o crescimento de algas e macrófitas, principalmente em ambientes aquático superficial e lêntico.

A presença de fósforo na água está relacionada a processos naturais (dissolução de rochas, carreamento do solo, decomposição de matéria orgânica, chuva) ou antropogênicos (lançamentos de esgotos, detergentes, fertilizantes e pesticidas). Em águas naturais não poluídas, as concentrações de fósforo situam-se na faixa de 0,01 a 0,05 mg.L $\mathrm{L}^{-1}$. Valores acima de 1,0 mg. $\mathrm{L}^{-1}$ geralmente são indicativos de águas poluídas. O fósforo por via antropogênica pode ser acrescido às águas subterrâneas por derivados de fertilizantes, detergentes, efluentes domésticos, inseticidas e pesticidas (FEITOSA et al., 2008).

A Portaria 2.914/2011 do Ministério da Saúde (BRASIL, 2011), não estabelece especificação para valores de fosfato.

Para as concentrações de fosfato é possível observar que nos períodos monitorados (estiagem e início do período chuvoso) não foi encontrados valores acima do limite de detecção do método utilizado. Apenas a cacimba C31 apresentou a concentração de aproximadamente 
1,0 mg.L $\mathrm{L}^{-1}$ no início do período chuvoso, o que provavelmente pode estar associado ao fato de localizar-se sob uma árvore com nome científico Bixa orellana L. e nome popular Urucum, recebendo contribuição direta de matéria orgânica.

Segundo Nascimento e Barbosa (2005), o fosfato não é tão preocupante quanto o nitrato, porque é menos móvel na água e, consequentemente, mais facilmente absorvido pela fração sólida do aquífero, atenuando sua influência como contaminante.

\section{Parâmetros bacteriológicos}

De acordo com Black (2002), coliformes são micro-organismos que habitam no intestino de animais de sangue quente, entre eles o homem, e estão presentes em suas excretas. Em contato com a água, as fezes humanas e até mesmo as de outros animais podem encontrar outro hospedeiro. A análise bacteriológica reforça e constata a poluição do aquífero freático por fossas sépticas e negras.

O grupo coliforme é normalmente usado como indicador da ausência ou da precariedade de um sistema de saneamento (VIEIRA \& OLIVEIRA, 2001). Os coliformes não provocam doenças; sua presença na água apenas indica que a ingestão do líquido poderá provocar patogenias por outros grupos de micro-organismos, já que no trato gastrointestinal, junto dos coliformes, podem ser liberadas também várias classes de organismos patogênicos, assim como solitárias, lombrigas e giárdias.

De acordo com a Portaria 2.914/2011 do Ministério da Saúde (BRASIL, 2011), uma amostra de $100 \mathrm{~mL}$ de água deveria apresentar ausência de bactérias do grupo coliformes, e as bactérias heterotróficas não deveriam ultrapassar 500 UFC. $100 \mathrm{~mL}^{-1}$.

Os resultados obtidos para a determinação do logaritmo do número mais provável de coliformes totais para os períodos monitorados (início e fim das chuvas) podem ser observados na Figura 4.

Das 31 amostras analisadas, todas (100\%) apresentaram concentração acima dos Valores Máximos Permissíveis ao Consumo Humano.

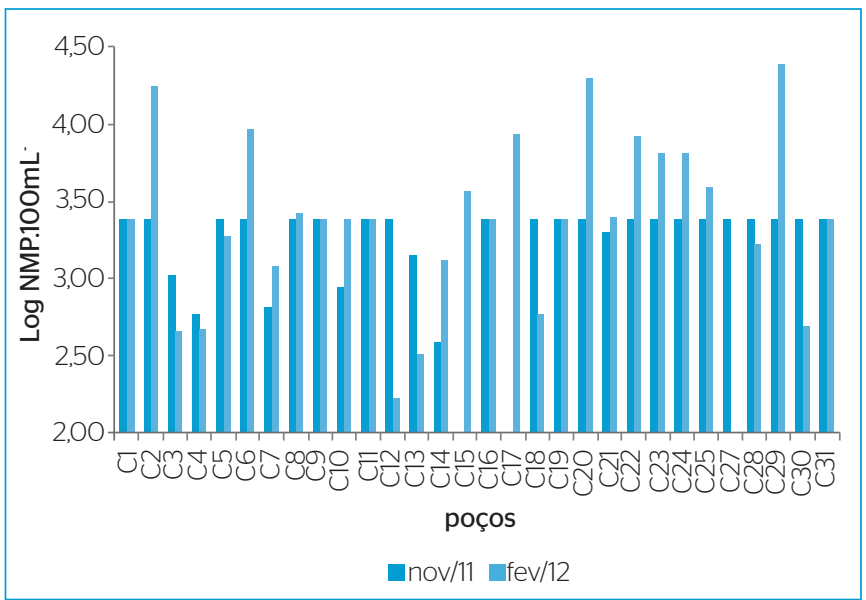

Figura 4 - Densidade de coliformes totais (Log NMP.100 mL) para o período chuvoso.
As concentrações variaram de 387,3 ao límite máximo de contagem da tabela, ou seja, o valor ultrapassou 2419,2 NMP.100 mL para o início do período chuvoso. No período chuvoso, os valores variaram entre 166,4 NMP.100 $\mathrm{mL}^{-1}$ ao limite máximo de contagem para o volume de amostra de água analisada.

Observa-se que a maior densidade de coliformes total foi encontrada no período chuvoso; em apenas nove cacimbas o inverso foi verificado: C3, C4, C5, C12, C13, C18, C27, C28 e C30. Em alguns casos a densidade foi igual para ambos os períodos monitorados: C1, C9, C11, C16, C19 e C31. A cacimba C31 foi selecionada a fim de que fosse considerada como valor de branco, ou seja, suas caracterítsticas físicas, químicas e biológicas não deveriam estar alteradas por atividades antrópicas; no entanto, foi verificado que mesmo essa cacimba se encontra contaminada por coliformes, o que possivelmente acontece por ser uma área onde há atividade de pecuária (foi observado durante as atividade de campo, um curral a montante do poço C31).

Os resultados obtidos já eram esperados, tendo em vista que o aquífero é freático, isto é, o nível d’água se encontra próximo à superfície do terreno, mostrando a vulnerabilidade à contaminação, principalmente por fossas negras, as quais estão maciçamente presentes no bairro Pedra Noventa. No final do período chuvoso ocorre uma elevação do nível d'água, e as fossas também sofrem essa elevação, aumentando a possibilidade de cofluência do material orgânico até o aquífero freático.

$\mathrm{Na}$ área em estudo, percebe-se o aumento da densidade de coliformes totais no período chuvoso. Esse aumento ocorre mais intensamente na região sudeste e leste, e separamente em dois pontos à norte e sudoeste: C17 e C2, respectivamente. No entanto, tratando-se de consumo humano, segundo a legislação pertinente, deveria ocorrer ausência de bactérias coliformes totais.

A água subterrânea se mantém fora do alcance dos olhares mais críticos ("o que os olhos não veêm o coração não sente"); por esse motivo, pode se tornar contaminada gradualmente, sem ao menos despertar a mínima atenção, sendo muitas vezes tarde demais para reverter o dano causado pela poluição. Assim, a única abordagem racional seria evitar a contaminação dos aquíferos freáticos.

A E. coli é subgrupo das bactérias do grupo coliformes, comprovadamente de origem fecal. Segundo Cardoso et al, 2003, a presença de E. coli indica contaminação recente, já que eles não se multiplicam nem persistem por um longo período, possuindo sobrevivência similar à das bactérias patogênicas.

De acordo com a Portaria 2.914/2011 do Ministério da Saúde (BRASIL, 2011), em amostras individuais procedentes de poços, fontes, nascentes ou outras formas de abastecimento sem distribuição canalizada, toleram-se a presença de coliformes totais, na ausência de E. coli. No entanto, esse não é o caso do estudo realizado no bairro Pedra Noventa, onde se observa alta densidade de coliformes totais na presença de E. coli. 
Os resultados obtidos para a densidade de E. coli na água dos poços rasos avaliados no bairro Pedra Noventa podem ser observados na Figura 5.

As cacimbas C15 e C17 não foram avaliadas no início do período chuvoso, pois se encontravam sem lâmina d'água suficiente para coleta. No final do período chuvoso a cacimba C17 apresentou $1 \mathrm{NMP} .100 \mathrm{~mL}^{-1}$ de E. coli e a cacimba C27 não foi analisada.

Das 31 análises realizadas, todas (100\%) apresentaram concentração acima dos Valores Máximos Permissíveis ao Consumo Humano. As concentrações acima do VMP variaram de 5,20 NMP.100 $\mathrm{mL}^{-1}$ ao valor máximo para leitura na tabela, ou seja, valor superior a 2419,2 NMP.100 mL ${ }^{-1}$ no início do período chuvoso. No final do período chuvoso as concentrações variaram de 1 a 11198,50 NMP.100 mL:

Dos resultados obtidos, cerca de 50\% dos valores da densidade de E. coli foram maiores para o início do período chuvoso, enquanto cerca de $44 \%$, no final do período chuvoso.

Há pontos em que a densidade de E. coli se encontra mais elevada no início do período chuvoso, mas no período chuvoso ocorre uma diminuição desses valores. Apenas as cacimbas C16 e C31 apresentaram maior densidade de bactérias E. coli no final do período chuvoso. Em decorrência de reações físicas, químicas e biológicas que ocorrem na zona não saturada, essa região acaba se tornando uma importante linha de defesa contra a poluição dos aquíferos freáticos. Pequenas espessuras de zona não saturada e proximidade das fossas com as águas do aquífero freático são fatores que favorecem a contaminação do aquífero. Sendo assim, possivelmente seja essa a causa associada à alta densidade de bactérias E. coli na área de estudo, no início do período chuvoso. Outro fator que deve ser considerado são as construções dos poços rasos na região, as quais não apresentam estrutura adequada e não seguem as normas pré-estabelecidas; com isso, há maior facilidade de contaminação.

A contagem de bactérias heterotróficas, genericamente definidas como micro-organismos, que requerem carbono orgânico como fonte de nutrientes, fornece informações sobre a qualidade bacteriológica da água de forma ampla, servindo, portanto, de indicador auxiliar da qualidade da água ao fornecer informações adicionais sobre eventuais falhas na desinfecção, colonização e formação de biofilmes no sistema de distribuição (GUERRA, 2006). A presença de bactérias heterotróficas em quantidades elevadas pode impedir a detecção de coliformes, seja por produção de fatores de inibição, seja por desenvolvimento mais intenso.

Para a determinação da densidade de bactérias heterotróficas, os resultados podem ser observados na Figura 6.

Com base na Figura 6, foi possível verificar que no início do período chuvoso a densidade das bactérias heterotróficas variou de 25 a 33.600 UFC. $\mathrm{mL}^{-1}$, apresentando valores acima dos limites recomendados em $75,86 \%$ das amostras analisadas. No final do período chuvoso, verificou-se menor ocorrência $(68,97 \%)$ e menores densidades (70 a 2650 UFC.mL').

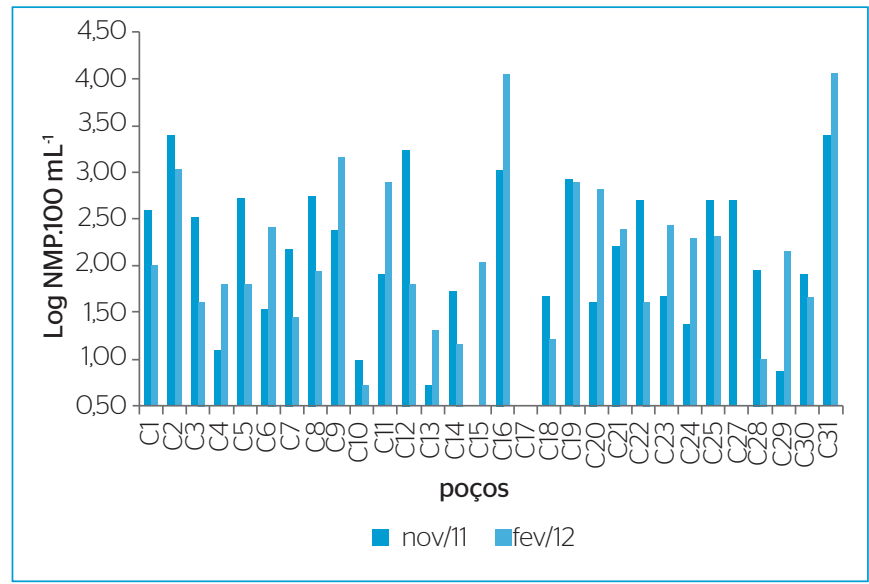

Figura 5 - Densidade de Escherichia coli (Log NMP.100 $\mathrm{mL}^{-1}$ ) para o período chuvoso.

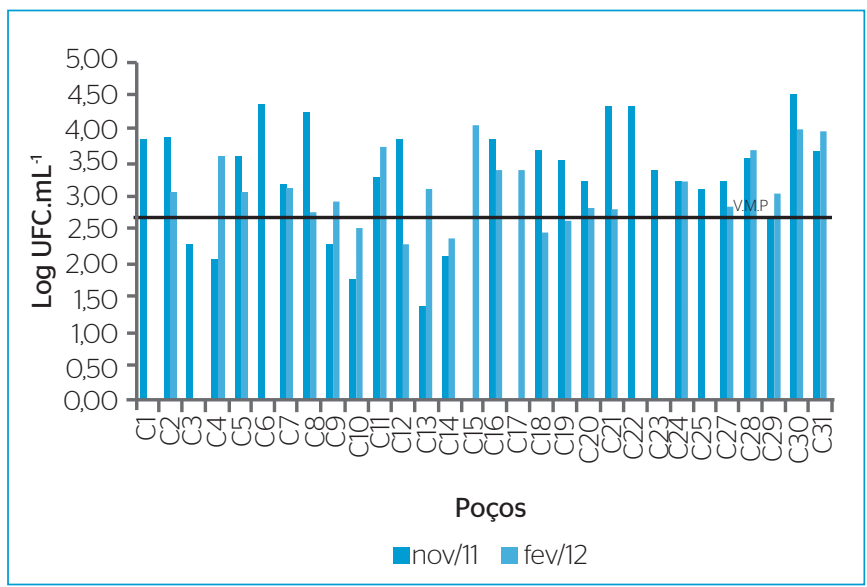

Figura 6 - Densidade de bactérias heterotróficas (Log UFC.mL') para o período chuvoso.

O uso generalizado de fossas séptica, negras ou drenos no bairro Pedra Noventa, onde os esgotos são lançados sobre ou abaixo da superfície do solo de várias maneiras, não somente contribui para que o esgoto filtrado alcance a superfície do terreno, como se constitui, provavelmente, numa das principais causas de contaminação da água subterrânea não somente na área em estudo como em todo o mundo.

Segundo Migliorini e Apoitia (2009), após avaliar 12 poços tubulares profundos na região de Cuiabá e Várzea Grande, verificaram que as concentrações de coliformes total e fecal nas águas se devem aos problemas de saneamento básico da região (grande quantidade de fossas sépticas, sumidouros e córregos contaminados), aliadas a poços tubulares com problemas construtivos. Essas informações são preocupantes, visto que esses autores avaliaram o aquífero em profundidade, enquanto este trabalho se dedica ao aquífero freático mais vulnerável. Nesse contexto, a região do bairro Pedra Noventa apresenta um cenário de maior risco, pois o elevado número de fossas negras, aliado a um nível d’água próximo à superfície do terreno, reduz o tempo de trânsito 
dos contaminantes gerados pelas fossas, já que o risco de alteração da qualidade natural das águas subterrâneas não é uma função apenas das características intrínsecas do aquífero, mas também ocorre pela existência de atividades poluidoras.

\section{CONCLUSÕES}

Os parâmetros químicos estudados não apresentaram concentrações muito elevadas, embora o $\mathrm{pH}$, a amônia, o nitrato e o fosfato tenham apresentado concentrações fora dos Valores Máximos Permissíveis para o consumo humano, exigidos pela Portaria 2.914/2011; provavelmente, originam-se das fossas sépticas, que estão disseminadas na região, e da matéria orgânica em decomposição que cai nos poços abertos.

Notou-se que ocorreram flutuações sazonais nas concentrações dos cátions e ânions, sendo as concentrações maiores na época da chuva e menores na época de estiagem, provavelmente em razão dos processos de lixiviação serem mais intensos que os processos de diluição.

As análises bacteriológicas (coliformes totais, E. coli e bactérias heterotróficas) apresentaram concentrações acima dos Valores Máximos Permissíveis para o consumo humano exigidos pela Portaria 2.914/2011, provavelmente por causa das fossas sépticas intensamente distribuídas na região.

As alterações provocadas nas águas subterrâneas do aquífero freático provavelmente se devem à falta de saneamento básico da região.

\section{AGRADECIMENTOS}

Os autores agradecem ao CNPq (processo: 574124/2008-8) pelo auxílio financeiro e à CAPES pela bolsa para Débora Delatore da Silva.

\section{REFERÊNCIAS}

AGÊNCIA NACIONAL DE ÁGUAS (ANA). Brasília, agosto/2002. Disponível em: <www.ana.gov.br/gestaoRecHidricos/infoHidrologicas/ projetos_aguasSubt $>$. Acesso em: 11 maio 2011.

ALVES OLIVEIRA, D.; GILDA, S.; FREITAS, M.D. Avaliação do teor de ferro em águas subterrâneas de alguns poços tubulares, no plano diretor de Palmas - TO. 2004. Net, Cuiabá, jan. 2012. Disponível em: $<$ www.bvsde. paho.org/bvsAIDIS/PuertoRico29/gilda.pdf > . Acesso em: 2 jan. 2012.

AMARAL, L.A.; NADER FILHO, A.; ROSSI JUNIOR, O. D.; FERREIRA, F.L.A.; BARROS, L.S.S. Água de consumo humano como fator de risco à saúde em propriedades rurais. Saúde Pública, v. 37, n. 4, 2003, p. 510-514.

AMERICAN PUPLIC HEALTH ASSOCIATION (APHA). Standard Methods for the Examination of Water and Wastewater - Method 3030-G: 21th Edition. 1998.

APOITIA, L.F.M. Caracterização preliminar do quimismo das águas subterrâneas em Cuiabá - MT. 2003. 130 f. Dissertação (Mestrado em Geologia) - Departamento de Geologia, Universidade Federal do Paraná, Curitiba, 2003.

ATHAYDE, G.B.; MULLER, C.V.; ROSA FILHO, E.F.; HINDI, E.C. Estudo sobre os tipos das águas do aquífero Serra Geral, no município de Marechal Cândido Rondon - PR. Águas Subterrâneas, v. 21, n. 1, 2007 , p. 111-122.

BLACK, J.G. Microbiologia: fundamentos e perspectivas. Rio de Janeiro: Guanabara Koogan, 2002. 829 p.

BRASIL. Ministério da Saúde. Portaria 2.914, de 12 de dezembro de 2011. Diário Oficial da União, Brasília, 14 de dezembro de 2011. Seção V. p. 32.
BRASIL, A.S. Avaliação da qualidade da água proveniente de poços tubulares profundos utilizados para abastecimento público no município de Cuiabá-MT. 2010. 59f. Monografia (Química - Bacharelado) Instituto de Ciências Exatas e da Terra, Departamento de química, Universidade Federal de Mato Grosso, Cuiabá, 2010.

CARDOSO, A.L.P.; TESSARI, E.N.C.; CASTRO, A.G.M.; KANASHIRO, A.M.I.; ZANATA, G.F. Incidência de coliforme e Salmonella sp. em águas provenientes de abatedouro avícola. Higiene Alimentar, v. 17, n. 111, 2003, p. 73-78.

CELLIGOI, A. Considerações sobre análises químicas de águas subterrâneas. Geografia, v. 8, n. 1, 1999, p. 91-97.

COLVARA, J.G.; LIMA, A.S.; SILVA, W.P. Avaliação da contaminação de água subterrânea em poços artesianos no sul do Rio Grande do Sul. Rio Grande do Sul, Brazillian Journal of food technology, 2009.

COMPANHIA DE TECNOLOGIA DE SANEAMENTO AMBIENTALCETESB. Coleta e Preservação de Amostras de Água. São Paulo: CETESB, 1988. (Procedimento Técnico).

COSTA, A.B.; KAUFMANN, R.C.; HANSEN, M.A.F.; KIRST, A.; LOBO, E.A. Avaliação da qualidade das águas subterrâneas em áreas de preservação permanente (sistema aquífero Guarani - SAG), bacia hidrográfica do Rio Pardo, RS, Brasil. TECNO-LÓGICA, v. 14, n. 1, 2010, p. 26-38

CRAUN GF. Causes of waterborne diseases in the United States. Water Sci Technol, n. 24, 1991, p. 17-20.

FEITOSA, F.A.C.; MANOEL FILHO, J.; FEITOSA, E.C.; DEMETRIO, J.G.A. SERVIÇO GEOLÓGICO DO BRASIL - CPRM. Hidrogeologia: conceitos e aplicações. Rio de Janeiro: CPRM: LABHID, 2008. 812 p. 
FERNíCOLA, N.G.G. \& AZEVEDO, F.A. Metemoblobinemia e nitrato nas águas. Revista de Saúde pública, v. 15, 1981, p. 242-248.

FINOTTI, A.R.; FINKLER, R.; D'AGOSTINI SILVA, M.; CEMIN GISELE. Monitoramento de Recursos Hídricos em Áreas Urbanas. Caxias do Sul: EDUCS, 2009. $272 \mathrm{p}$.

FIORUCCI, A.R. \& BENEDETTIFILHO, E. Aimportância do Oxigênio Dissolvido em Ecossistemas Aquáticos. Química Nova na Escola, n. 22, 2005, p. 1-7.

FREEZE, A. \& CHERRY, J.A. Groundwater. New Jersey: Prentice-Hall, Englewood Cliffs, 1979. 604 p.

FREITAS, L.C.B. Qualidade das águas subterrâneas - área do município de Caucaia, região metropolitana de Fortaleza - Ceará. 2009. 93 f. Dissertação (Mestrado em Geologia) - Centro de Ciências, Departamento de Geologia, Universidade Federal do Ceará, Fortaleza, 2009

GALVÃO, M.V. (Org.). Geografia do Brasil, grande região centro-oeste. Rio de Janeiro: Conselho Nacional de Geografia, 1960. 452 p.

GUERRA, N.M.M.; OTENIO, M.H.; SILVA, M.E.Z.; GUILHERMETTI, M.; NAKAMURA, C.V.; NAKAMURA, T.U.; DIAS FILHO, B.P. Ocorrência de Pseudomonas aeruginosa em água potável. Acta Scientiarum Biological Sciences, n. 28, 2006, p. 13-18.

KRONE, R.B.; McGAUHEY, P.H.; GOTAAS, H.B. Direct discharge of groundwater with sewage effluents. Journal Sanitary Engineering Division, v. 83, 1957, p. 1-25.

MARION, F.A.; CAPONE, V.; SILVA, J.L.S. Avaliação da qualidade da água subterrânea em poço no campus da UFSM, Santa Maria - RS. Ciência e Natura, n. 29, v. 1, 2007, p. 97-109.

MIGLIORINI, R.B. Hidrogeologia em meio urbano: região de Cuiabá e Várzea Grande - MT. 1999. 146 f. Tese (Doutorado em Geologia) - Instituto de geociências, Universidade de São Paulo (USP), São Paulo, 1999.

MIGLIORINI, R.B.; APOITIA, L.F.M. Águas subterrâneas: caracterização da hidrogeologia na região da bacia hidrográfica do rio Cuiabá In bacia do Rio Cuiabá: uma abordagem socioambiental. Cuiabá: EDUFMT, 2009.

MISRA, K.K. Safe water in rural areas. International Journal of Health Education. n. 18, 1975, p. 53-59.

NASCIMENTO, S.A.M. \& BARBOSA, J.S.F. Qualidade da água do aquífero freático no alto cristalino de Salvador, bacia do rio Lucaia, Salvador, Bahia. Revista Brasileira de Geociências, v. 35, n. 4, 2005, p. 543-550.
PEREIRA, R.S. Poluição Hídrica: causas e consequências. Revista eletrônica de Recursos Hídricos, v. 1, n. 1, 2004, p. 20-36. Disponível em: <www.abrh.org.br/informacoes/rerh.pdf>. Acesso em 3 out. 2013.

PERLMUTTER, N.M.; LIEBER, M.; FRAUENTHAL, H.L. Contamination of ground water by detergents in a suburban environment: south Farmingdale area, Long Island. U. S. Geological Survey. Professional Paper, n. 501-C, 1964, p. 170-175.

PINFOLD, J.V. Faecal contamination of water and fingertip-rinses as a method for evaluatingthe Effect of low cost water supply and sanitation activies on faecal-oral disease transmission. II. A hygiene intervention study in rural north-est Thailand. Epidemiol Infect, n. 105, 1990, p. 377-380.

REETZ, E.F. Avaliação quali-quantitativa dos recursos hídricos superficiais na bacia hidrográfica do Campus da Universidade Federal de Santa Maria. 2002. 121 f. Dissertação (Mestrado em Engenharia Civil) - Universidade Federal de Santa Maria, 2002.

REIS, J.A.T. \& MENDONÇA, A.S.F. Teores limites para compostos amoniacais em efluentes e corpos receptores - conflitos e inter-relações. 1995. Net, Cuiabá, abr. 2012. Disponível em: <www.bvsde.paho.org/ bvsacd/abes97/teorias.pdf>. Acesso em: 24 abr. 2012.

ROCHA, T.S. Avaliação da qualidade das águas dos poços tubulares da bacia do Rio do Peixe equipados com dessalinizadores, com vistas ao aproveitamento econômico dos sais de rejeito. 2008. 96 f. Dissertação (Mestrado profissional em gerenciamento e tecnologias ambientais no processo produtivo) - Departamento de Engenharia ambiental (DEA) Universidade Federal da Bahia, Salvador, 2008.

STANDARD Methods for the Examination of Water and Wasterwater. $16^{\text {th }}$ ed. Baltimore: Port City Press, 1985. p. 373.

VIEIRA, R.H.S.F. \& OLIVEIRA, R.A. Avaliação do grau de contaminação fecal da água e do camarão sossego (Macrobrachium jelskii), na Lagoa Parangaba (Fortaleza, Ceará). Higiene Alimentar, v. 15, n. 85, p. $61-64,2001$.

WESNER, G.M. \& BAIER, D.C. Injection of reclaimed wasterwater into confined aquifers. Journal of the American Water Works Association, n. 62, 1970, p. 203-210.

ZAVOUDAKIS, E. Impactos da urbanização sobre a qualidade da água freática em áreas de Vitória, ES. 2007. 221 f. Dissertação (Mestrado em Engenharia Ambiental) - Centro tecnológico, Universidade Federal do Espírito Santo, Vitória, 2007. 